WARSZTATY Z GEOGRAFII TURYZMU

ISBN 978-83-7969-262-0 $\quad$ s. 225-238

http://dx.doi.org/10.18778/7969-262-0.15

Justyna MAJEWSKA

Uniwersytet Ekonomiczny w Poznaniu

\title{
ZJAWISKO KONCENTRACJI PRZESTRZENNEJ PODMIOTÓW GOSPODARCZYCH SEKTORA TURYSTYKI - PRZYKLAD POLSKI I NIEMIEC
}

\section{Bliskość przestrzenna podmiotów gospodarczych i jej konsekwencje - wprowadzenie i przegląd literatury}

Przestrzenna koncentracja działalności gospodarczej wynika z możliwości osiągania pozytywnych efektów ekonomicznych przez podmioty zlokalizowane na danym obszarze (tworzące skupisko przestrzenne, klaster ${ }^{1}$ ). Jest to jedna z najbardziej znanych cech współczesnej geografii ekonomicznej (KRUGMAN 1991). Występowanie efektów przestrzennych w postaci korzyści skali sprzyja m.in. koncentracji firm oferujących komplementarne produkty i usługi oraz napływowi wysoko kwalifikowanych pracowników, a także powstawaniu sieci społecznych i biznesowych ułatwiających dyfuzję wiedzy i technologii (FuJITA, THISSE 2002, DURANTON, PUGA 2004, SøRENSEN 2007, WOlFE 2009, DOLOREUX, SHEARMUR 2012). Zgodnie z tradycyjną teorią

\footnotetext{
${ }^{1}$ Klaster rozumiany jest w opracowaniu jako skupisko przestrzennej aktywności gospodarczej, która może - ale nie musi - stanowić przesłankę wykształcenia się sformalizowanej struktury gospodarczej. Samo bowiem występowanie koncentracji podmiotów gospodarczych w przestrzeni nie musi świadczyć o silnych powiązaniach i interakcjach między nimi. Niemniej prawdopodobieństwo ich wystąpienia rośnie wraz ze wzrostem liczby podmiotów tworzących skupisko i spadkiem odległości między nimi (BRODZICKI, KUCZEWSKA, red. 2012, s. 62).
} 
lokalizacji w decyzjach lokalizacyjnych poza czynnikami kosztowymi ważną rolę odgrywają czynniki popytowe - duży i powiększający się rynek (BAUM, HAVEMAN 1997).

W turystyce skupianie się firm w określonej lokalizacji ma również związek z jej atrakcyjnością. Atrakcyjność ta może wynikać z walorów naturalnych lub antropogenicznych tworzących tzw. rdzeń produktu (turystyka wypoczynkowa, specjalistyczna czy uzdrowiskowa), bądź też z atrakcji umożliwiających realizacje innych celów podróży (turystyka zakupowa, biznesowa, kulturowa). Rodzaj tych atrakcji ma wpływ na kształtowanie się procesów koncentracji przestrzennej podaży i popytu w regionach turystycznych. $Z$ reguły producenci muszą dostosować swoje decyzje lokalizacyjne do miejsc koncentracji ruchu turystycznego. Może jednak wystąpić sytuacja, w której przestrzenna koncentracja producentów staje się magnesem przyciągającym ruch turystyczny, gdy chęć osiągnięcia większej użyteczności jest przyczyną decyzji lokalizacyjnych względem popytu (GOŁEMBSKI, MAJEWSKA 2014).

Podmioty $\mathrm{w}$ regionie turystycznym (przedsiębiorstwa turystyczne, firmy działające w pokrewnych sektorach i związane $\mathrm{z}$ nimi instytucje), funkcjonujące we wzajemnej bliskości przestrzennej, wchodzą w specyficzne relacje współzależności, współpracując i konkurując ze sobą - jak w koncepcji Porterowskiego klastra (PORTER 1998, 2001)². Korzyściami wynikającymi z takiego postępowania są nie tylko oszczędności kosztów i duży popyt, ale także możliwości współdziałania między firmami. Tego rodzaju zachowania są typowe dla rynku turystycznego ze względu na heterogeniczność i komplementarność produktu turystycznego oraz podaży turystycznej, powodujących współzależność wielu sektorów (GOŁEMBSKI, MAJEWSKA 2014).

Należy przy tym rozróżnić efekty lokalizacyjne i urbanizacyjne koncentracji przestrzennej podmiotów gospodarczych w nawiązaniu do, odpowiednio, koncepcji Mashalla z 1890 r. i Jacobs z 1969 r. (zob. BEAUDRY, SCHIFFAUEROVA 2009). Pierwsze z nich odzwierciedlają korzyści specjalizacji wewnątrzsektorowej, a drugie odnoszą się do korzyści czerpanych ze zróżnicowania sektorowego firm i prowadzenia działalności gospodarczej na obszarach o dużej gęstości zaludnienia. Stąd badanie zjawiska koncentracji przestrzen-

2 Zgodnie z podejściem Portera, klaster definiuje się jako geograficzne skupisko wzajemnie powiązanych firm, wyspecjalizowanych dostawców, jednostek świadczących usługi, firm działających w pokrewnych sektorach i związanych z nimi instytucji w poszczególnych dziedzinach, konkurujących między sobą, ale też współpracujących (PORTER 2001, s. 246). 
nej powinno uwzględniać nie tylko efekty specjalizacji sektorowej, ale też tzw. koaglomeracji, czyli tendencji do lokowania działalności gospodarczej przez zróżnicowane sektory we wzajemnej bliskości (ELLISON, GLAESER, KERR 2007). Rozróżnienie odzwierciedlających różne korzyści aglomeracji typów klastrów zdaje się mieć kluczowe znaczenie w turystyce, która rozwija się zarówno na obszarach monokultury turystycznej, jak i w uzupełnieniu zróżnicowanej funkcji gospodarczej regionów (miasta, obszary zurbanizowane).

Jednocześnie trzeba zauważyć, że turystyka rozwija się także na styku regionów, niezależnie od administracyjnego podziału kraju na jednostki terytorialne, dla których gromadzone są dane statystyczne opisujące zjawisko koncentracji przestrzennej działalności gospodarczej. Aby uchwycić ten rozwój należy uwzględnić $\mathrm{w}$ badaniach występowanie, charakter oraz siłę współzależności między regionami ze względu na lokalizację podmiotów sektora turystyki i przeprowadzić przestrzenną analizę danych z wykorzystaniem odpowiednich narzędzi, na co wskazuje się w literaturze przedmiotu (zob. np. BRODZICKI, KUCZEWSKA 2012, CARROLL, REID, SMITH 2008). W szczególności istotne zdaje się być uchwycenie pozytywnych efektów rozprzestrzeniania się zjawiska koncentracji przestrzennej działalności gospodarczej w turystyce na sąsiednie obszary (tzw. geograficzne spillovers) oraz ich braku czy tendencji przeciwnych - przy uwzględnieniu różnych typów koncentracji przestrzennej. Jak pokazują bowiem przeprowadzone m.in. w ramach programu ESPON 2013 badania, znaczenie konkretnych układów terytorialnych, "miejsc” w globalnej gospodarce stale rośnie (ESPON 2013). Stąd efekty przestrzenne, tj. przestrzenna zależność i przestrzenna heterogeniczność (ANSELIN 2010), stanowią podstawę analizowania zachowań ekonomicznych podmiotów gospodarczych w świetle tzw. nowej geografii ekonomicznej - najnowszego nurtu teorii lokalizacji działalności gospodarczej.

W związku z powyższym głównym celem artykułu jest zilustrowanie zjawiska koncentracji przestrzennej podmiotów sektora turystyki w polskich i niemieckich regionach oraz określenie występowania i siły zjawiska tzw. geograficznych spillovers, tj. rozlewania się aktywności gospodarczej w sektorze turystyki na sąsiednie jednostki terytorialne. Dobór obszaru badań miał na celu uchwycenie zjawiska koncentracji przestrzennej sektora turystyki w zróżnicowanych układach terytorialnych, z uwzględnieniem policentrycznego systemu osadniczego (jak w Polsce) i silnych ośrodków metropolitalnych (Niemcy). 


\section{2. Źródła danych i metoda badania}

Badanie przeprowadzono na podstawie danych zgromadzonych przez polską i niemiecką statystykę publiczną, tj. Główny Urząd Statystyczny i Statistisches Bundesamt Deutschland. W badaniu uwzględniono jednostki terytorialne na poziomie NUTS-4 w Polsce (379 powiatów) i NUTS-3 w Niemczech (412 jednostek) w analizowanym okresie, tj. w 2012 i 2008 r. W ten sposób, przyjmując różne poziomy dezagregacji danych statystycznych, w badaniach uwzględniono porównywalną liczbę jednostek terytorialnych w dwóch krajach.

Do określenia koncentracji podmiotów gospodarczych sektora turystyki przyjęto liczbę przedsiębiorstw zarejestrowanych $\mathrm{w}$ danej jednostce terytorialnej według sekcji i działów zgodnie z europejską klasyfikacją aktywności gospodarczej (NACE). Uwzględniono działalność związaną z zakwaterowaniem i usługami gastronomicznymi (sekcja I), działalność związaną z kulturą, rozrywką i rekreacją (sekcja R, dział 93), a także działalność organizatorów turystyki, agentów i pośredników turystycznych oraz pozostałą działalność usługową w zakresie rezerwacji i działalności z nią związane (sekcja $\mathrm{N}$, dział 79) $)^{3}$.

Z wykorzystaniem map jako narzędzia wizualizacji określono koncentrację przestrzenną sektora turystyki $\mathrm{w}$ ujęciu absolutnym (rozkład przestrzenny liczby podmiotów gospodarczych zarejestrowanych ogółem w analizowanych sekcjach i działach) oraz w ujęciu względnym. Przy tym w badaniu zastosowano powszechną miarę relatywnej koncentracji działalności gospodarczej - współczynnik lokalizacji (Location Quotient, LQ), służący do identyfikacji regionalnych skupień (klastrów) na podstawie porównania struktury zatrudnienia czy aktywności ekonomicznej podmiotów w regionie i na poziomie wyższym, np. całego kraju (BRODZICKI, KUCZEWSKA, red. 2012, Fundacja BFKK 2010, FESER, LUGER 2003, COOK, PANDIT, LÖÖF, JOHANSSON 2012). W ten sposób, przyjmując jako zmienną liczbę podmiotów gospodarczych zarejestrowanych w sektorze turystyki, wyznaczono wskaźnik gęstości tych podmiotów zgodnie $\mathrm{z}$ formułą:

$$
L Q=\left(P_{i j} / P_{j}\right) /\left(P_{i n} / P_{n}\right)
$$

${ }^{3}$ Ze względu na brak możliwości pozyskania danych na niższym poziomie dezagregacji sektorowej, w przypadku Niemiec w badaniu uwzględniono podmioty gospodarcze zarejestrowane w sekcji I oraz R ogółem (a nie według działów). 
gdzie:

$P_{i j}$ - liczba podmiotów gospodarczych w sektorze (turystyki) w regionie,

$j, P_{j}$ - całkowita liczba podmiotów gospodarczych w regionie,

$j, P_{\text {in }}$ - liczba podmiotów gospodarczych w sektorze (turystyki) ogółem w kraju,

$P_{n} \quad$ - całkowita liczba podmiotów gospodarczych w kraju.

Wysokość wskaźnika lokalizacji LQ powyżej jedności wskazuje na ponadprzeciętną koncentrację danej cechy w stosunku do średniej krajowej, a więc może stanowić o regionalnej specjalizacji sektorowej.

Ponadto przeprowadzono analizę współzależności przestrzennych badanej zmiennej w ujęciu regionalnym (w jednostkach terytorialnych na poziomie NUTS-3 i NUTS-4), tj. z wykorzystaniem narzędzi eksploracyjnej analizy danych przestrzennych (ESDA) zbadano występowanie i charakter powiązań pomiędzy regionami ze względu na lokalizację podmiotów gospodarczych sektora turystyki oraz ich statystyczną istotność. Tym samym oszacowano i przetestowano lokalne mierniki autokorelacji przestrzennej (Local Indicators of Spatial Association, LISA) z wykorzystaniem lokalnej statystyki Morana I. Statystyka ta jest wyznaczana w celu stwierdzenia, czy wartości zmiennej w danym regionie zależą (i w jaki sposób) od jej wartości w regionach sąsiednich, zgodnie $z$ określonym schematem sąsiedztwa ${ }^{4}$ (BRODZICKI, KUCZEWSKA, red. 2012). Jeżeli analizowana jest zmienna X, to dla określonej macierzy wag standaryzowanej wierszami statystyka Morana $I$ wyznaczana jest według formuły (SUCHECKI, red. 2010):

$$
I=\frac{\sum_{i=1}^{N} \sum_{j=1}^{N} w_{i j}\left(x_{i}-\bar{x}\right)\left(x_{j}-\bar{x}\right)}{\sum_{i=1}^{N}\left(x_{i}-\bar{x}\right)^{2}}
$$

gdzie:

$x_{i}$ - wartość analizowanej zmiennej w regionie $i$,

$\bar{x}$ - średnia arytmetyczna zmiennej

$x, w_{i j}$ - elementy macierzy wag.

Statystyka Morana I jest ważonym współczynnikiem korelacji służącym do wykrywania w rozkładzie losowym zmiennej X odchyleń o charakterze

${ }^{4}$ Sąsiedztwo może być określone na wiele różnych sposobów, np. sąsiadami są regiony mające wspólną granicę czy regiony, dla których odległość pomiędzy geometrycznymi środkami (lub stolicami regionów) nie przekracza określonej liczby kilometrów itd. (zob. szerzej: SUCHECKI 2010 i KOPCZEWSKA 2011). 
przestrzennym, czyli pozwala ustalić, czy sąsiadujące ze sobą obszary są bardziej do siebie podobne (z punktu widzenia zmiennej X), niż wynikałoby to ze stochastycznego charakteru badanego zjawiska (SUCHECKI, red. 2010, s. 113).

\section{Przestrzenna koncentracja sektora turystyki i geograficzne spillovers w Polsce (NUTS-4) i w Niemczech (NUTS-3)}

Na mapach (rys. 1-4) przedstawiono rozkład przestrzenny podmiotów gospodarczych sektora turystyki (koncentracja w ujęciu absolutnym) oraz wskaźników gęstości tych podmiotów (LQ), ilustrujących relatywną koncentrację sektora turystyki na poziomie NUTS-4 w Polsce (rys. 1 i 2) i NUTS-3 w Niemczach (rys. 3 i 4). Wartości graniczne klas analizowanych wielkości

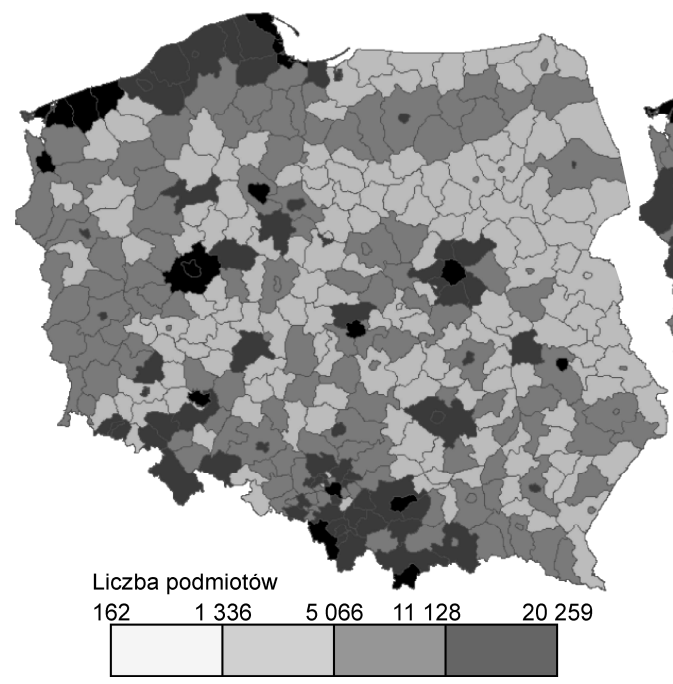

Rys. 1. Rozkład podmiotów gospodarczych sektora turystyki w 2012 r. według powiatów w Polsce

Źródło: opracowanie własne na podstawie danych GUS z wykorzystaniem programu PQStat

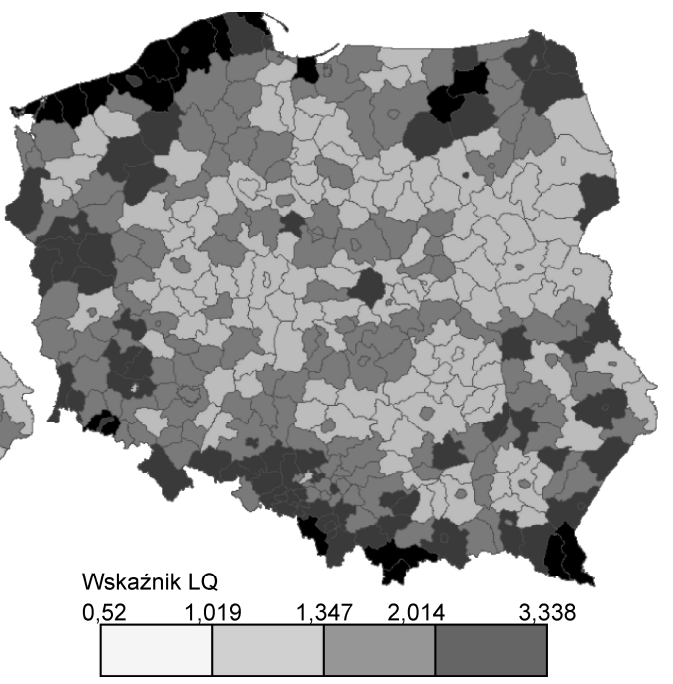

Rys. 2. Rozkład gęstości (wskaźników LQ) podmiotów gospodarczych sektora turystyki w 2012 r. według powiatów w Polsce Źródło: opracowanie własne na podstawie danych GUS z wykorzystaniem programu PQStat 


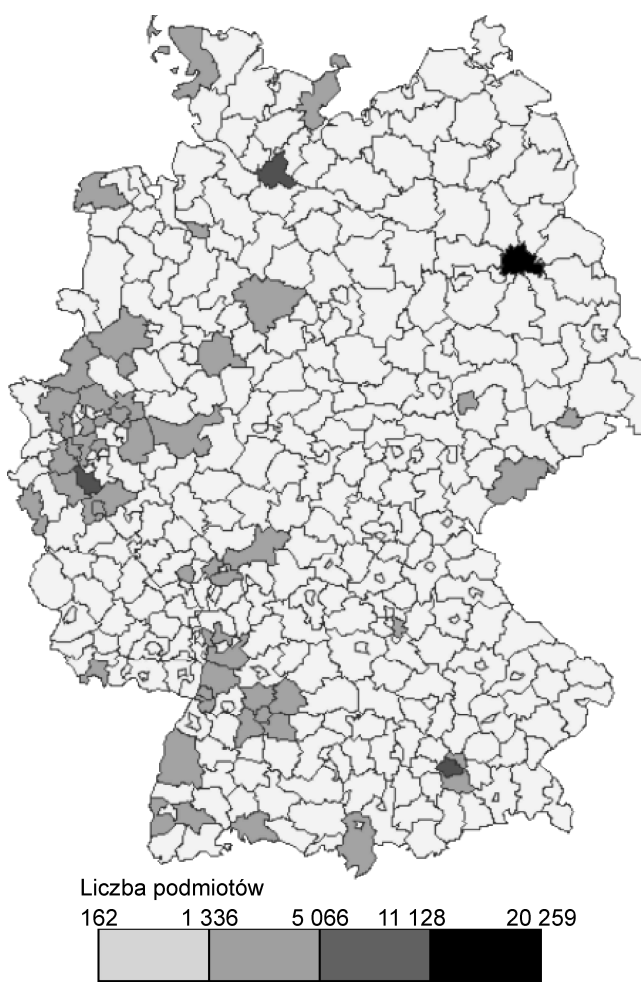

Rys. 3. Rozkład podmiotów gospodarczych sektora turystyki w Niemczech (NUTS-3) w $2008 \mathrm{r}$.

Źródło: opracowanie własne na podstawie danych niemieckiego urzędu statystycznego zwykorzystaniem programu PQStat

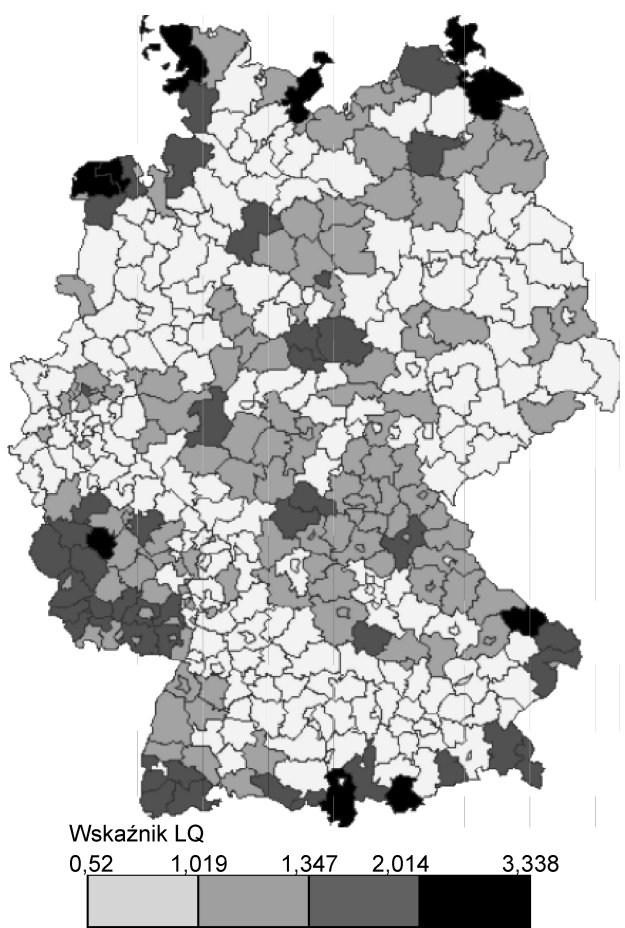

Rys. 4. Rozkład gęstości (wskaźników LQ) podmiotów gospodarczych sektora turystyki w Niemczech (NUTS-3) w 2008 r.

Źródło: opracowanie własne na podstawie danych niemieckiego urzędu statystycznego z wykorzystaniem programu PQStat

ustalono na podstawie algorytmu Fishera-Jenksa, wskazującego tzw. natural breaks ${ }^{5}$.

Analizując koncentrację podmiotów gospodarki turystycznej w ujęciu absolutnym w obu krajach można zauważyć, że skupiają się one w miastach i $\mathrm{w}$ otoczeniu niektórych miast oraz $\mathrm{w}$ najbardziej rozwiniętych regionach tradycyjnej turystyki wypoczynkowej (wybrzeże, regiony górskie, pojezierza). Niektóre z nich tworzą szersze, ponadregionalne skupiska, co ma m.in. związek z lokalizacją i liniowym charakterem samych atrakcji turystycznych

${ }^{5}$ Idea algorytmu polega na tym, że dzieli obserwacje na grupy w taki sposób, że zróżnicowanie (wariancja) między grupami jest największe, natomiast wariancja wewnątrz każdej z grup jest możliwie najmniejsza. 
(pasma górskie, wybrzeża), ale może też wynikać z powiązań funkcjonalnych jednostek terytorialnych i korzyści aglomeracji oraz wynikających z nich efektów geograficznych spillovers; inne stanowią "samotne wyspy" w otoczeniu obszarów o niewielkiej liczbie podmiotów zarejestrowanych $\mathrm{w}$ sektorze turystyki. Biorąc natomiast pod uwagę rozkład przestrzenny wskaźnika gęstości podmiotów gospodarczych sektora turystyki (ujęcie relatywne) można zauważyć - obok wysokich wartości tego wskaźnika na terenach tradycyjnej turystyki wypoczynkowej - niedoszacowanie miast i obszarów zurbanizowanych o zdywersyfikowanej funkcji gospodarczej na rzecz jednostek terytorialnych, które charakteryzują się niższą, a czasem nawet niewielką (w ujęciu absolutnym) liczbą zarejestrowanych w sektorze turystyki podmiotów gospodarczych, ale za to ważniejszą, na tle innych sektorów lokalnej gospodarki, funkcją turystyczną (np. Pojezierze Meklemburskie w Niemczech czy polskie Mazury). Stosowanie zatem w analizie regionalnych skupisk działalności gospodarczej w turystyce wyłącznie względnej miary specjalizacji sektorowej na podstawie wskaźnika LQ jest niewystarczające. Takie podejście badawcze pozwala bowiem na uchwycenie tylko jednego typu koncentracji przestrzennej, tj. klastrów lokalizacyjnych, opartych na wewnątrzsektorowej specjalizacji (obszary monokultury turystycznej). Niemniej z punktu widzenia efektów ekonomicznych powiązań w układzie: miasto i jego otoczenie regionalne, ważny jest także drugi typ - tj. klastry urbanizacyjne (korzyści dla sektora turystyki wynikające z bliskości zdywersyfikowanych sektorowo podmiotów gospodarczych). Biorąc zatem pod uwagę fakt, że podmioty gospodarki turystycznej koncentrują się zarówno na obszarach o dominacji funkcji turystycznej, jak i na terenach, gdzie turystyka stanowi jedną z wielu funkcji gospodarczych (obszary zurbanizowane) ważne staje się pytanie o znaczenie każdego z typów koncentracji przestrzennej działalności biznesowej w tworzeniu efektów geograficznych spillovers w turystyce.

W celu uchwycenia tych efektów w kolejnym kroku wyznaczono wartości lokalnej statystyki Morana I, które umożliwiają analizowanie rozmiarów istotnych skupień podobnych wartości cechy wokół poszczególnych lokalizacji (sąsiadujące ze sobą jednostki terytorialne). W ten sposób zlokalizowano klastry, czyli miejsca o zwiększonej lub zmniejszonej intensywności badanej cechy6. Rozprzestrzenianie się zjawiska lokalizacji podmiotów gos-

${ }^{6}$ W wyniku tej analizy można wyróżnić: obszary o wysokich wartościach otoczone przez obszary o wysokich wartościach (high-high), obszary o niskich wartościach otoczone przez obszary o niskich wartościach (low-low), obszary o niskich wartościach otoczone przez obszary o wysokich 
podarki turystycznej można przy tym analizować na podstawie różnych miar sąsiedztwa. Może być ono określone m.in. na podstawie wspólnej granicy (przynajmniej jeden punkt na płaszczyźnie - tzw. macierz wag przestrzennych królowej) czy zadanej odległości pomiędzy geometrycznymi środkami lub stolicami regionów (SUCHECKI, red. 2010, KOPCZEWSKA 2011). Należy przy tym zauważyć, że przyjęcie określonej miary sąsiedztwa rzutuje na wyniki przeprowadzonej autokorelacji przestrzennej i charakter zidentyfikowanych reżimów przestrzennych.

W przeprowadzonym badaniu najwyższe wartości statystyki uzyskano dla macierzy kontyngencji stopnia pierwszego, czyli macierzy, w której za sąsiadów uznano jednostki terytorialne posiadające wspólną granicę (macierz królowej). Zestawienie różnych wartości statystyki Morana I dla różnych, standaryzowanych wierszami macierzy wag przestrzennych podano w tab. 1.

Tabela 1. Wartości statystyki Morana I wyznaczone dla różnych macierzy wag przestrzennych (standaryzacja wierszami) na poziomie NUTS-4 w Polsce i NUTS-3 w Niemczech

\begin{tabular}{|l|c|c|}
\hline \multicolumn{1}{|c|}{$\begin{array}{c}\text { Macierz wag przestrzennych } \\
\text { (typ sąsiedztwa) }\end{array}$} & $\begin{array}{c}\text { Statystyka } \\
\text { Morana I } \\
\text { (Polska) }\end{array}$ & $\begin{array}{c}\text { Statystyka } \\
\text { Morana I } \\
\text { (Niemcy) }\end{array}$ \\
\hline W1 - sąsiedztwo określone wspólną granicą & $\mathbf{0 , 1 2 4}$ & $\mathbf{0 , 0 5 7}$ \\
\hline W2 - sąsiedzi w promieniu 50 km od geometrycznego środka & 0,047 & 0,045 \\
\hline W3 - sąsiedzi w promieniu 75 km od geometrycznego środka & 0,027 & 0,021 \\
\hline W4 - sąsiedzi w promieniu 100 km od geometrycznego środka & 0,021 & 0,025 \\
\hline W5 - sąsiedzi w promieniu 150 km od geometrycznego środka & $-0,0001$ & 0,013 \\
\hline
\end{tabular}

Źródło: opracowanie własne na podstawie danych urzędów statystycznych Polski i Niemiec, z wykorzystaniem programu PQStat.

Rozkład przestrzenny statystyki Morana I w odniesieniu do liczby przedsiębiorstw sektora turystyki w polskich i niemieckich jednostkach terytorialnych zaprezentowano na kolejnych mapach poniżej (rys. 5-8).

Na podstawie uzyskanych wartości statystyki Morana I stwierdzono występowanie - w zależności od przyjętej miary sąsiedztwa - dodatniej i ujemnej autokorelacji przestrzennej. W pierwszym przypadku można mówić o skupianiu się jednostek terytorialnych charakteryzujących się wysoką ak-

wartościach (low-high) i obszary o wysokich wartościach otoczone przez obszary o niskich wartościach (high-low). 
tywnością gospodarczą w sektorze turystyki, co może świadczyć o występowaniu pozytywnych efektów geograficznych spillovers. Dotyczy to jednostek oznaczonych na zamieszczonych mapach najciemniejszym odcieniem szarości (obszary o wysokich wartościach otoczone przez obszary o wysokich wartościach analizowanej zmiennej). W odniesieniu do Polski są to (w oparciu o sąsiedztwo wyznaczone przez wspólną granicę) niektóre duże miasta (Kraków, Poznań, Gdańsk), Warszawa i niektóre powiaty aglomeracji warszawskiej oraz obszary tradycyjnej turystyki wypoczynkowej - nadmorskiej i górskiej (powiat wejherowski, pucki, tatrzański). Powiaty te tworzą szersze, ponadregionalne skupiska przestrzenne aktywności gospodarczej $\mathrm{w}$ turystyce - klastry ponadregionalne. $W$ przypadku Niemiec na uwagę zasługuje policentryczna aglomeracja w Zagłębiu Ruhry z dużą liczbą małych, zlokalizowanych obok siebie jednostek terytorialnych czy Stuttgart z otaczającymi miasto sąsiadami, tworzącymi specyficzny układ lokalizacyjny. Specyfika położenia tych jednostek terytorialnych sprzyja uzyskiwaniu statystycznie istotnych wartości statystyki Morana I w przypadku sąsiedztwa określonego wspólną granicą.

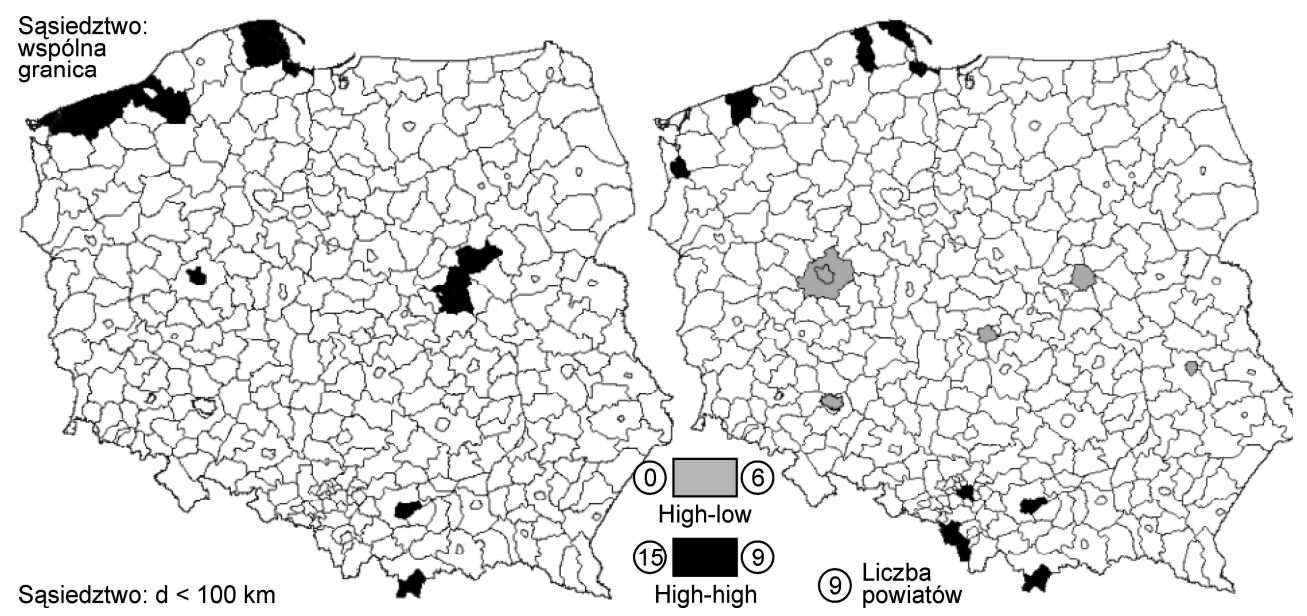

Rys. 5. Istotne statystycznie wartości lokalnej statystyki Morana I w odniesieniu do podmiotów sektora turystyki w polskich powiatach w $2012 \mathrm{r}$. Źródło: jak pod rys. 1 i 2.
Rys. 6. Istotne statystycznie wartości lokalnej statystyki Morana I w odniesieniu do podmiotów sektora turystyki w polskich powiatach w $2012 \mathrm{r}$.

Źródło: jak pod rys. 1 i 2. 


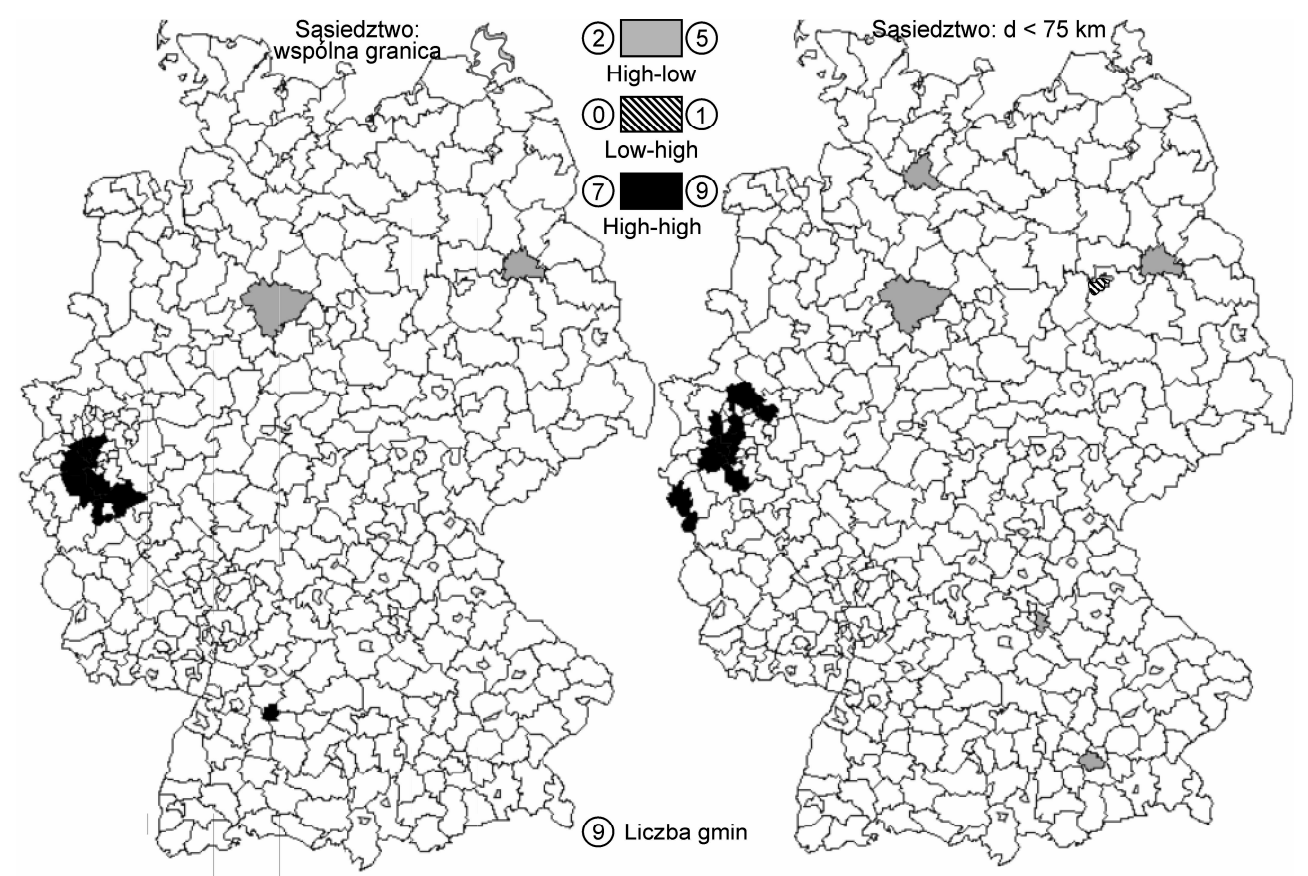

Rys. 7. Istotne statystycznie wartości lokalnej statystyki Morana I w odniesieniu do podmiotów sektora turystyki w Niemczech (NUTS-3) w $2008 \mathrm{r}$.

Źródło: jak pod rys. 3 i 4.
Rys. 8. Istotne statystycznie wartości lokalnej statystyki Morana I w odniesieniu do podmiotów sektora turystyki w Niemczech (NUTS-3) w $2008 \mathrm{r}$.

Źródło: jak pod rys. 3 i 4.

Natomiast w drugim przypadku, gdy obiekt otoczony jest przez regiony o znacząco różnych wartościach badanej zmiennej, można mówić o występowaniu „outliersów” (do których zaliczają się regiony o ponadprzeciętnie wysokich wartościach zmiennej, otoczone niskimi wartościami - oznaczone na mapach jasnoszarym odcieniem). W przypadku Niemiec są to, niezależnie od przyjętej macierzy wag przestrzennych (typu sąsiedztwa), m.in. Berlin i Hannover. Na przykładzie tych miast obserwuje się zjawisko odwrotne do pozytywnych efektów spillovers $\mathrm{w}$ układzie: metropolia i jej otoczenie regionalne (brak ponadregionalnych skupisk działalności gospodarczej w turystyce). Warto zauważyć, że w przypadku Polski, przy zastosowaniu miary sąsiedztwa w postaci maksymalnej odległości od środka powiatu równej 100 km, również można mówić o negatywnych efektach spillovers, np. w odniesieniu do Warszawy, Poznania i otaczającego miasto powiatu poznańskiego, Łodzi czy Wrocławia. Jednakże przyjęcie występowania wspólnej 
granicy powiatów za miarę sąsiedztwa sprawia, że jeśli występowały w tych przypadkach istotne statystycznie współzależności przestrzenne, to były to efekty pozytywne.

\section{Wnioski i podsumowanie}

Zastosowanie $\mathrm{w}$ przeprowadzonych badaniach przestrzennej analizy danych z wykorzystaniem statystyki Morana I umożliwiło określenie siły i charakteru powiązań między jednostkami terytorialnymi na poziomie NUTS-4 w Polsce i NUTS-3 w Niemczech ze względu na koncentrację podmiotów sektora turystyki. Pozwoliło to tym samym na uchwycenie rozwoju turystyki poza granicami administracyjnymi regionów - w wyniku tzw. geograficznych spillovers, przy uwzględnieniu różnych typów aglomeracji przestrzennej podmiotów sektora turystyki (klastry lokalizacyjne i urbanizacyjne). Takie efekty rozprzestrzeniania się zjawiska koncentracji podmiotów gospodarki turystycznej mogą być szczególnie widoczne i istotne $\mathrm{w}$ przypadku policentrycznego układu osadniczego, jaki występuje w Polsce, zwłaszcza wobec wdrażanego obecnie dyfuzyjno-polaryzacyjnego modelu polityki regionalnej. $W$ ramach przeprowadzonej analizy przestrzennej zidentyfikowano także efekty przeciwne (negatywne), tj. występowanie wyizolowanych obszarów wysokiej koncentracji aktywności gospodarczej w sektorze turystyki, zwłaszcza w układzie metropolia-region, co zaobserwowano w odniesieniu do dużych niemieckich miast (Berlin, Hannover, Monachium).

Na podstawie przeprowadzonych badań wykazano występowanie reżimów przestrzennych - wzorców rozkładu przestrzennego aktywności gospodarczej w turystyce. Dostrzeżono zróżnicowanie oddziaływania obszarów o wysokiej liczbie podmiotów gospodarczych zarejestrowanych w sektorze turystyki na otaczające obszary i możliwość osiągania przez nie przewagi związanej z korzyściami aglomeracji w różnych typach aglomeracji (koncentracji przestrzennej). Cechy przestrzeni odgrywają zatem istotne znaczenie w wyjaśnianiu regionalnej koncentracji podmiotów gospodarki turystycznej. Proces ten zależy od lokalizacji w przestrzeni, a bardziej szczegółowy wgląd w strukturę rozmieszczenia przestrzennego aktywności gospodarczej $\mathrm{w}$ turystyce $\mathrm{w}$ polskich i niemieckich jednostkach terytorialnych umożliwiło zastosowanie lokalnych współczynników autokorelacji przestrzennej (statystyka lokalna Morana I). Trzeba jednak zauważyć, że staty- 
styka ta jest wrażliwa m.in. na rodzaj przyjętej miary sąsiedztwa regionów (wspólna granica, określony dystans między centrami geometrycznymi analizowanych obszarów) oraz samo wytyczenie granic jednostek terytorialnych (wielkość, kształt, zgodność z powiązaniami funkcjonalnymi obszarów). Jej zastosowanie wiąże się zatem z pewnymi ograniczeniami metodologicznymi i musi być poprzedzone odpowiednią refleksją na temat zakresu możliwych rekomendacji pod kątem polityki turystycznej.

\section{BIBLIOGRAFIA}

ANSELIN L., 2010, Thirty years of spatial econometrics, „Papers in Regional Science”, 89, 1, March, s. $3-25$.

BAUM J.A.C., HAVEMAN H.A., 1997, Love by neighbor? Differentiation and agglomeration in the Manhattan hotel industry, 1898-1990, "Administrative Science Quarterly”, 42, s. 304-338.

BEAUDRY C., SCHIFFAUEROVA A., 2009, Who's right, Marshall or Jacobs? The localization versus urbanization debate, „Research Policy”, 38, s. 318-337.

BRODZICKI T., KUCZEWSKA J. (red.), 2012, Klastry i polityka klastrowa w Polsce. Konkurencyjność przedsiębiorstw, sektorów i regionów, Wyd. Uniwersytetu Gdańskiego, Gdańsk.

CARROLL C.M., REID N., SMITH B.W., 2008, Location quotients versus spatial autocorrelation in identifying potential cluster regions, "The Annals of Regional Science”, 42, s. 449-463. DOI: 10.1007/s00168007-0163-1.

COOK G.A.S., PANDIT N.R., LÖÖF H., JOHANSSON B., 2012, Geographic clustering and outward foreign direct investment, „International Business Review”, 21, s. 1112-1121.

DOLOREUX D., SHEARMUR R., 2012, Collaboration, information and the geography of innovation in knowledge intensive business services, ,JJournal of Economic Geography", 12, s. 79-105.

DURANTON D., PUGA D., 2004, Micro-foundations of urban agglomeration economies, [w:] V. HENDERSON, J.F. THISSE (red.), Handbook of Regional and Urban Economics, 4, Elsevier, Amsterdam, s. 2063-2117.

ELLISON G., GLAESER E.L., KERR W., 2007, What causes industry agglomeration? Evidence from coagglomeration patterns, „Harvard Business School Working Papers”, 07-064.

ESPON, 2013, Seminaria i konferencje: Konferencja „Polityka miejska - wyzwania, doświadczenia, inspiracje", http://www.espon.pl/strona/konferencja_polityka_miejska; 20.06.2013.

FESER E.J., LUGER M.I., 2003, Cluster Analysis as a Mode of Inquiry: Its Use in Science and Technology Policymaking in North Carolina, „European Planning Studies”, 11, s. 11-24.

FuJITA M., THISSE J.F., 2002, Economics of Agglomeration, Cambridge University Press, Cambridge.

Fundacja BFKK, 2010, Klastry jako potencjał rozwoju - województwo podlaskie, Raport, Białostocka Fundacja Kształcenia Kadr w Białymstoku, http://www.bfkk.pl /libs/ckfinder/userfiles/files/ badania_i_ekspertyzy/RAPORT_KLASTRY_CAIY_DRUK.pdf.

GOŁEMBSKI G., MAJEWSKA J., 2014, Zjawisko aglomeracji przestrzennej a produktywność w turystyce przykład Polski, [w:] G. Gołembski, A. Niezgoda (red.), Turystyka wobec zmian wspótczesnego świata, Wydawnictwo Uniwersytetu Ekonomicznego w Poznaniu, Poznań (w druku).

KOPCZEWSKA K., 2011, Ekonometria $i$ statystyka przestrzenna $z$ wykorzystaniem programu $R$ CRAN, CeDeWu, Warszawa.

KRUGMAN P., 1991, Geography and Trade, Leuven University Press, Leuven.

PORTER M.E., 1998, On Competition, Harvard Business Review Press, Boston. 
PORTER M.E., 2001, Strategy and the Internet, „Harvard Business Review”, March, s. 62-78.

SØRENSEN F., 2007, The geographies of social networks and innovation in tourism, „Tourism Geographies", 9, 1, s. 22-48.

SUCHECKI B. (red.), 2010, Ekonometria przestrzenna. Metody $i$ modele analizy danych przestrzennych, Wyd. C.H. Beck, Warszawa.

WOLFE D., 2009, Introduction: embedded clusters in a global economy, „European Planning Studies”, 17, s. 179-187.

\section{SPATIAL AGGLOMERATION OF TOURISM FIRMS - EXAMPLE OF POLAND AND GERMANY}

Key words: agglomeration, tourism sector, location quotients, spatial association, Polish districts, German regions

\section{Summary}

The research subject of the paper is the spatial agglomeration phenomenon in tourism - the concentration of firms registered in the tourism sector, including both types of the agglomeration economies: localization- and urbanization-driven clusters. Agglomeration phenomenon is measured on the basis of statistics within regional administrative boundries. In tourism it is crucial to capture spatial dependency between the phenomena in neighboring regions outside the boundries, hence there is a need to capture geographic spillovers - as proposed in the paper by applying local indicators of spatial association.

We used the data collected by the Central Statistical Office in Poland and Germany at NUTS-4 and NUTS-3 level. In order to study the spatial concentration of the tourism sector and its linkages with neighboring regions we used location quotients and the methods of the explorative spatial data analysis. The study have revealed that Moran's I statistic is sensitive to the measures of the neighborhood identification and localization of the territorial units boundaries. 